\title{
Salinity tolerance of larvae Aedes aegypti inland and coastal habitats in Pasangkayu, West Sulawesi, Indonesia
}

\author{
ARINI RATNASARI ${ }^{1, \boldsymbol{v}}$, ARIF RAHMAN JABAL ${ }^{2}$, SYAHRIBULAN ${ }^{3}$, IRFAN IDRIS $^{4}$, NUR RAHMA ${ }^{5}$, \\ SRI NUR RAHMI NUR RUSTAM ${ }^{5}$, MILA KARMILA ${ }^{5}$, HAJAR HASAN $^{5}$, ISRA WAHID ${ }^{5, \vee \varphi}$ \\ ${ }^{1}$ Graduate School, Faculty of Medicine, Universitas Hasanuddin. Jl Perintis Kemerdekaan Km. 10, Makassar 902425, South Sulawesi, Indonesia. \\ Tel./fax.: +62-819-53001991, `email: ratnasaria18c@sstudent.unhas.ac.id \\ ${ }^{2}$ Departmen of Parasitology, Faculty of Medicine, Universitas Palangka Raya. Jl. Yos Sudarso, Palangka Raya 73112, Central Kalimantan, Indonesia \\ ${ }^{3}$ Departmen of Biology, Faculty of Mathematics and Natural Sciences, Universitas Hasanuddin. J1 Perintis Kemerdekaan Km. 10, Makassar 902425, \\ South Sulawesi, Indonesia \\ ${ }^{4}$ Departmen of Physiology, Faculty of Medicine, Universitas Hasanuddin. J1 Perintis Kemerdekaan Km. 10, Makassar 902425, South Sulawesi, Indonesia \\ ${ }^{5}$ Faculty of Medicine, Universitas Hasanuddin. J1 Perintis Kemerdekaan Km. 10, Makassar 902425, South Sulawesi, Indonesia. Tel./fax.: +62-411- \\ 586010, Fax.: +62-411-586297, •vemail: israwahid@med.unhas.ac.id
}

Manuscript received: 22 October 2020. Revision accepted: 10 February 2021.

\begin{abstract}
Ratnasari A, Jabal AR, Syahribulan, Idris I, Rahma N, Rustam SNRN, Karmila M, Hasan H, Wahid I. 2021. Salinity tolerance of larvae Aedes aegypti inland and coastal habitats in Pasangkayu, West Sulawesi, Indonesia. Biodiversitas 22: 1203-1210. Aedes aegypti L. is the primary arboviral vector generally found in freshwater, but it is also observed in brackish water. The study analyzes habitat characteristics, larvae adaptation, and oviposition preference in salinity levels over the coastal and inland ecosystem in Pasangkayu District of West Sulawesi. The larvae were reared until adults and have larval of first progeny were examined the salinity tolerance in five salinity levels. Ovitrap-based experiments were carried out in the laboratory using adult Ae. aegypti colonies from inland and coastal areas. Eggs on filter paper (ovitrap) were identified and counted. Data were analyzed using LC50 (larvae with salinity tolerance) and Pearson correlation (correlation between the larvae phase two ecosystem factors). Total larvae observed in coastal areas and inland are 1437 and 1288, respectively. The salinity tolerance test showed that Instar IV is highly adapted to the saline environment. The larvae from the coastal (inland) area can tolerate salinity up to 13 (10) ppt. Mosquitoes can lay many eggs in 3 ppt salinity: $27.1 \%$ and $20.8 \%$ for coastal and inland colonies, respectively. Pearson correlation analysis showed a significant correlation between the larval instar stage of Ae. aegypti from coastal and inland ecosystems with the ability to survive at the salinity level (p < 0.01$)$. This study is expected to be a source of information on the adaptation of Ae. aegypti mosquito to salinity in coastal and inland ecosystems. The findings can be considered in vector control efforts on brackish water habitats.
\end{abstract}

Keywords: Aedes aegypti, coastal, inland, Pasangkayu, salinity

\section{INTRODUCTION}

Arboviral diseases have been widely reported in the world (Soni et al. 2020). The vector that causes the disease (dengue, yellow fever, and chikungunya) in humans over the tropical and sub-tropical countries is Aedes aegypti and Ae. albopictus (Diptera: Culicidae) (Ramasamy et al. 2011; Augustina et al. 2020). Globally, there are 3.97 billion people in 128 countries at risk of this disease. Dengue vector breeding sites are not given much attention in coastal areas. Brackish water habitats are a neglected source of dengue fever vectors on tropical beaches in the world (Ramasamy and Surendran 2012).

Aedes. aegypti larvae found in a used drink containing brackish water in coastal areas with a salinity of 2-14 ppt and in wells with a salinity of 2-9 ppt (Surendran et al. 2012). Results of a laboratory study on Ae. aegypti from coastal Thirunelvely tolerated 18 ppt salinity and in inland Batticaloa adapted to salinity of $14 \mathrm{ppt}$, in Sri Lanka (Ramasamy et al. 2011). Results of a laboratory study on Ae. aegypti from coastal tolerated $18 \mathrm{ppt}$ salinity and in inland adapted to salinity of $12 \mathrm{ppt}$, in Jaffna District, Sri Lanka (Ramasamy et al. 2011). In Brunei Darussalam, Ae. aegypti from coastal tolerated 10 ppt salinity and in inland adapted to salinity of $8 \mathrm{ppt}$ (Idris et al. 2013).

The information on the adaptability of Ae. aegypti to salinity in coastal and inland areas, especially in the Pasangkayu District (Formerly Mamuju Utara District), West Sulawesi Province, Indonesia is essential to know the salinity level to control the spread of the dengue vector. Bambalamotu (i.e. Randomayang coastal area) and Martajaya Sub-districts are endemic areas of DHF every year (West Sulawesi Health Office 2020). DHF cases continue to increase in West Sulawesi every year, and the highest is in Pasangkayu District with two sub-districts of Bambalamotu and Martajaya. This study aimed to analyze the habitat characteristics, larvae adaptation, and oviposition preference in salinity levels. This research is expected as a source of information on the salinity adaptability of Ae. aegypti in two different ecosystems in Pasangkayu District.

\section{MATERIALS AND METHODS}

This experimental study tested the salinity tolerance of Ae. aegypti from coastal Randomayang and inland Martajaya, Pasangkayu District, West Sulawesi, Indonesia. 


\section{Study area}

Larvae were collected on the coast of Pasangkayu District from January to August 2020. The coastal sampling location is at coastal Randomayang, Bambalamotu Sub-district, Pasangkayu District, West Sulawesi $\left(-1^{\circ} 03^{\prime} 46.9^{\prime \prime} \mathrm{S}, 119^{\circ} 27^{\prime} 58.8^{\prime \prime} \mathrm{E}\right)$. The inland area covers the Martajaya Sub-district of Pasangkayu District, West Sulawesi $\left(-1^{\circ} 10^{\prime} 23.9^{\prime \prime} \mathrm{S}, 19^{\circ} 24^{\prime} 52.8^{\prime \prime} \mathrm{E}\right)$ with the consideration that the location is located on the outskirts of the city center with easy access and densely populated (Figure 1).

\section{Larval collection}

Sampling was collected by searching for Ae. aegypti breeding habitat in inland and coastal area. All larvae were collected using a Pasteur pipette. The water salinity of larvae habitat was used with a refractometer and salt meter (Lutron YK-31SA). The instrument was calibrated with a solution of 0 to $30 \mathrm{ppt}$ sodium chloride in the laboratory, and the measurement of water $\mathrm{pH}$ was done by $\mathrm{pH}$ meter. All larvae with water in the containers were transferred to the sample bottles and labeled, then the distance of the sample coordinates from the coastline used GPS (Garmin Montana 680). All samples were brought to the Entomology Laboratory of Faculty Medicine, Hasanuddin University, Makassar, Indonesia.

\section{Mosquito identification}

The identified larvae were positioned on glass objects by a needle. The observation was conducted with a stereomicroscope (Nikon SMZ745) with 10x-40x magnification by a taxonomic identification key of Aedes larvae, refer to Ministry of Health, Indonesia (2017).

\section{Tolerance test}

Aedes. aegypti larvae collected from coast were reared by using seawater taken in their natural habitat and $A e$. aegypti larvae from inland were reared by using freshwater. Larvae were fed with fish pellets twice a day. Larvae were reared until adults using separate sterile cages in a laboratory with temperature $28^{\circ} \mathrm{C}$ and humidity $60-80 \%$. Female adult Ae. aegypti were fed with blood mice and male adults fed sugar water. The result mated of first progeny, larvae were used for the salinity tolerance test. The salinity tolerance test was done on Instars I, II, III, and IV. Dilution of seawater made by mixing seawater with freshwater to form salinity of $0,3,5,10,15$, and 20 ppt. Measurement of salinity used a salt meter (Lutron YK31SA) to determined salinity levels. Ten larvae for each instar I-IV were put in a plastic container filled with saline water at levels $0,3,5,10,15$, and 20 ppt. Furthermore, it was closed using plastic to avoid evaporation. The test was repeated three times in parallel for each salinity level. The number of larvae Ae. aegypti that succeeded in becoming adult mosquitoes recorded for each level of salinity.

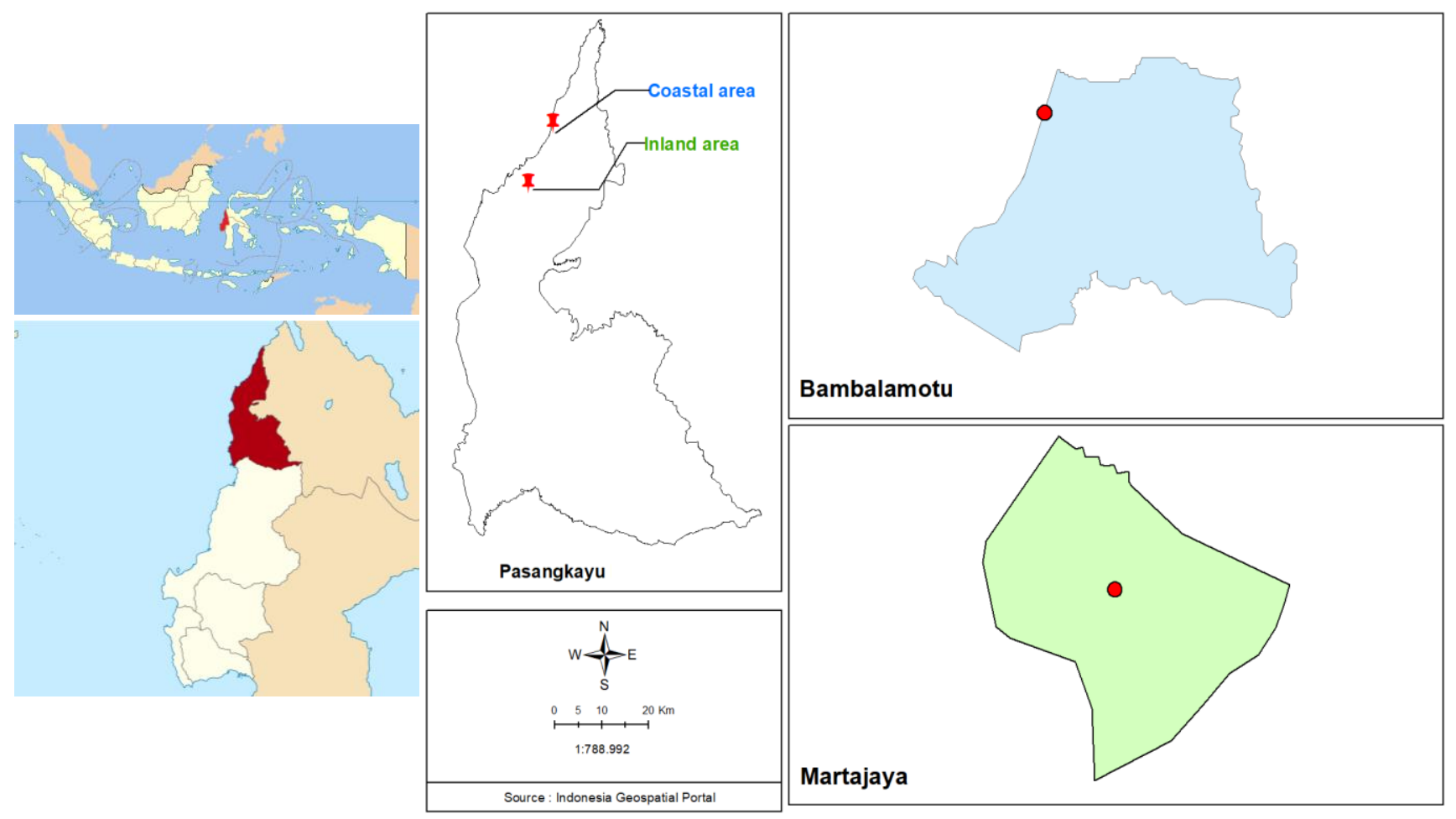

Figure 1. Two sampling locations (red marker): Bambalamotu Sub-district for coastal area and Martajaya Sub-district for inland area of West Sulawesi Province, Indonesia 
Oviposition preference for fresh and brackish water in laboratory

A total of 60 adult mosquitoes (30 females and 30 males) were put in each of six mosquito cages. Water with salinity levels of $0,3,5,10,15$ and 20 ppt was put into each plastic container in each cage. Filter paper used as an ovitrap was put in the container. Counting mosquito eggs trapped in ovitrap was conducted every week and was done for four weeks (Surendran et al. 2007).

\section{Ethics}

This research did approve by the Health Research Ethics Committee of the Hasanuddin University Medical Faculty with the attached number 558/UN4.6.4.5.31/PP36/2020.

\section{Data analyze}

The distribution of Ae. aegypty larvae mapped using ArcGIS geographic information system software version 10.5. Habitat characteristics and percentage of larvae from coastal and inland analyzed chi-square analysis. Larval survival and salinity tolerance used probit analysis and ratio test (LC50) with a confidence limit of 95\% (Wheeler et al. 2006). The correlation between larval stages from two habitat ecosystems analyzed Pearson correlation IBM SPSS version 24.

\section{RESULTS AND DISCUSSION}

\section{Larval distribution}

Distribution of Ae. aegypti in the coastal area was $52.7 \%(\mathrm{n}=1437)$ and inland was $47.3 \%(\mathrm{n}=1288)$. The larval habitat characteristics in the two ecosystems showed the highest acidity level in the drum water species (Table
1). The distribution of larvae visually is shown in Figure 2. Survival and salinity tolerance of Ae. aegypti in the coastal Randomayang and the inland Martajaya in the Pasangkayu district are presented graphically (Figure 3) with the relevant parameters tabulated (Table 2).

\section{Survival larva Ae. aegypti in coastal and inland habitats}

The larval survival curves in the two ecosystems differ along the gradient of the salinity assay. Both populations (Coastal and Inland) had a 100\% survival rate in controls (0 ppt). Instar III and IV larvae survived at 3 and 5 ppt salinity in more than $90 \%$ of coastal ecosystems. A sharp reduction of about $50 \%$ of the observed survival rate occurred at 15 ppt salinity, and total mortality occurred at 20 ppt salinity. Instar III and IV larvae survived in 3 and 5 ppt salinity in more than $80 \%$ inland ecosystem. A sharp reduction of about $50 \%$ of the observed survival rate occurred at $10 \mathrm{ppt}$ salinity, and total mortality occurred at $20 \mathrm{ppt}$ salinity (Figure 3).

Table 2. Salinity tolerance of Ae. aegypti larvae in the laboratory

\begin{tabular}{|c|c|c|c|}
\hline Ecosystems & $\begin{array}{c}\text { Larva } \\
\text { Ae. } \\
\text { aegypti } \\
\text { stage }\end{array}$ & $\begin{array}{l}\text { Maximum salinity } \\
\text { tolerance } A e . \\
\text { aegypti larvae for } \\
100 \% \text { adulthood in } \\
\text { salinity }\end{array}$ & $\mathrm{LC}_{50}$ ppt (CI) \\
\hline \multirow[t]{4}{*}{ Coastal } & $1^{\text {st }}$ & 8 & $10.9(10-11,8)$ \\
\hline & $2^{\text {nd }}$ & 8 & $10.8(9.9-11.7)$ \\
\hline & $3^{\text {rd }}$ & 10 & $12.6(11.7-13.5)$ \\
\hline & $4^{\text {th }}$ & 10 & $13.1(12.1-14.0)$ \\
\hline \multirow[t]{4}{*}{ Inland } & $1^{\text {st }}$ & 5 & $9.5(8.6-10.4)$ \\
\hline & $2^{\text {nd }}$ & 7 & $9.7(8.8-10.7)$ \\
\hline & $3^{\text {rd }}$ & 8 & $10.0(9.3-11.0)$ \\
\hline & $4^{\text {th }}$ & 9 & $10.8(9.9-11.6)$ \\
\hline
\end{tabular}

Note: $\mathrm{LC}_{50}$ test with $\mathrm{CI}-95 \%$ confidence interval

Table 1. Distribution and Characteristic habitat larva Ae. aegypti in coastal and inland area

\begin{tabular}{|c|c|c|c|c|c|c|c|c|}
\hline Region & Container type & $\begin{array}{c}\text { Containers } \\
\text { inspected }\end{array}$ & $\begin{array}{c}\text { Positive } \\
\text { container }\end{array}$ & $\begin{array}{c}\text { Positive } \\
\%\end{array}$ & pH & $\begin{array}{c}\text { Salinity } \\
\text { (ppt) }\end{array}$ & $\begin{array}{c}\text { Number of } \\
\text { larva }\end{array}$ & \% Larva \\
\hline \multirow[t]{11}{*}{ Randomayang } & Coconut shell & 5 & 2 & 40 & 5.9 & 4 & 8 & 0.3 \\
\hline & Wooden boat & 10 & 6 & 60 & 5.9 & 4 & 189 & 6.9 \\
\hline & Well & 10 & 3 & 30 & 6.4 & 2 & 144 & 5.3 \\
\hline & Plastic glass & 5 & 2 & 40 & 5.9 & 4 & 21 & 0.8 \\
\hline & Discarded buckets & 20 & 6 & 30 & 6 & 3 & 247 & 9.1 \\
\hline & Drums & 20 & 10 & 50 & 6.7 & 1 & 410 & 15.0 \\
\hline & Flower pot & 10 & 5 & 50 & 7 & 0 & 130 & 4.8 \\
\hline & Discarded tires & 10 & 4 & 40 & 7 & 0 & 248 & 9.1 \\
\hline & Discarded cans & 5 & 1 & 20 & 6 & 3 & 10 & 0.4 \\
\hline & Concreate tank & 5 & 1 & 20 & 6.7 & 1 & 30 & 1,1 \\
\hline & & 100 & 40 & 40 & 6.4 & 2.2 & 1437 & 52.7 \\
\hline \multirow[t]{9}{*}{ Martajaya } & Bathtub & 10 & 4 & 40 & 7 & 0 & 168 & 6.2 \\
\hline & Used buckets & 10 & 10 & 20 & 6.9 & 0 & 80 & 2.9 \\
\hline & Used tires & 15 & 15 & 26,67 & 7 & 0 & 199 & 7.3 \\
\hline & Flower pot & 15 & 15 & 46,67 & 7 & 0 & 154 & 5.7 \\
\hline & Used cans & 10 & 10 & 60 & 7 & 0 & 136 & 5.0 \\
\hline & Trash can & 15 & 15 & 53,33 & 7 & 0 & 157 & 5.8 \\
\hline & Cans cat & 15 & 15 & 46,67 & 6.5 & 0 & 133 & 4.9 \\
\hline & Drum water & 10 & 10 & 60 & 7 & 0 & 261 & 9.6 \\
\hline & & 100 & 94 & 44.17 & 6.9 & $\mathbf{0}$ & 1288 & 4.3 \\
\hline
\end{tabular}



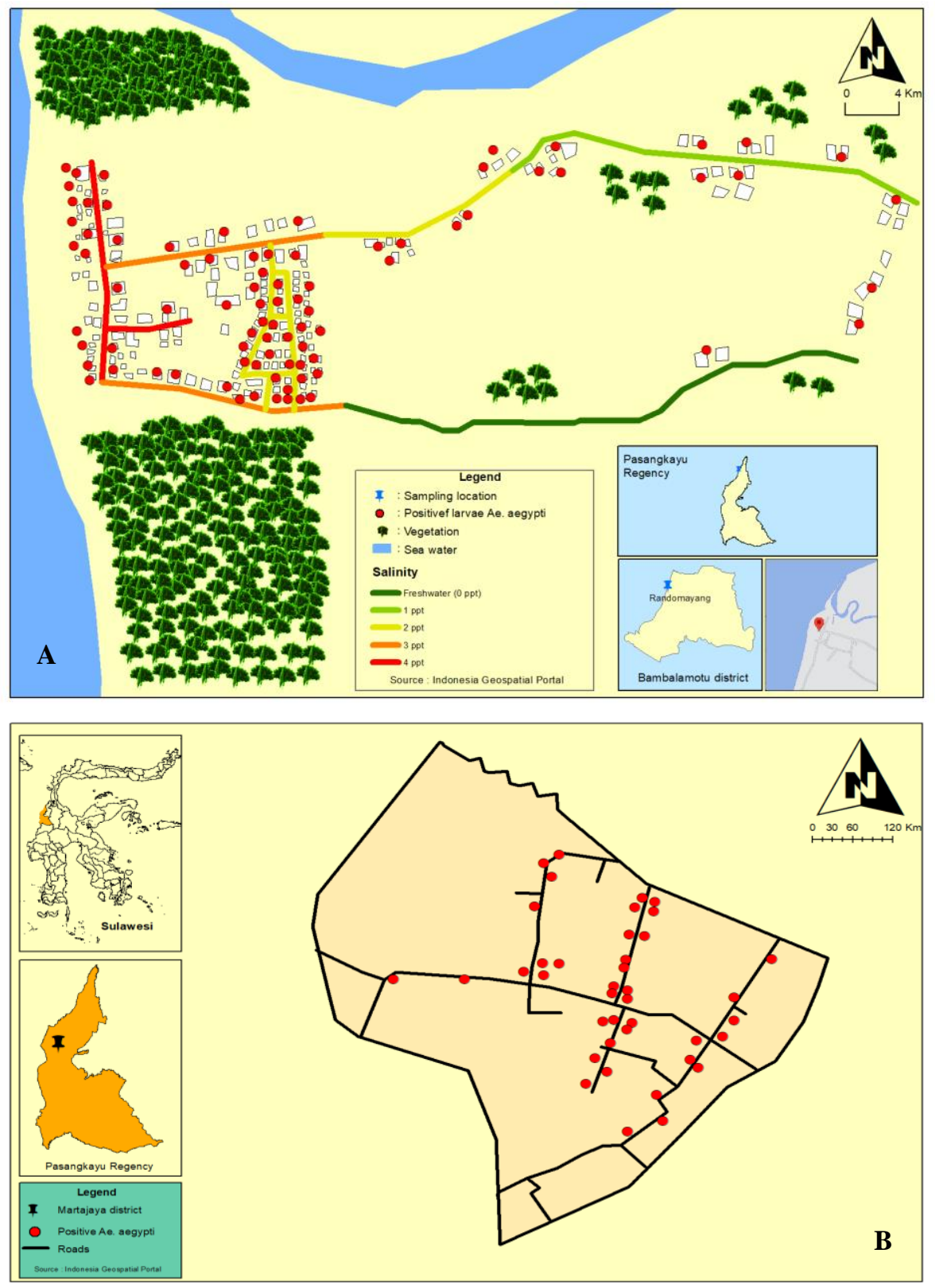

Figure 2. A. Distribution map of Ae. aegypti in coastal area, B. Distribution of Ae. aegypti in inland area of Pasangkayu District, West Sulawesi, Indonesia

\section{Salinity tolerance of Ae. aegypti larvae}

Tolerance of Ae.aegypti larvae to salinity from the $\mathrm{LC}_{50}$ test showed differences in each instar stage. Instar IV is highly adapted to salinity to become adult mosquitoes. Two ecosystems show that coastal areas are better able to tolerate salinity up to $13 \mathrm{ppt}$ while inland can only tolerate salinity up to $10 \mathrm{ppt}$ (Table 2).

\section{Adaptability to lay eggs in various salinity levels}

Aedes. aegypti usually lay their eggs in freshwater, but these mosquitoes are adapted to different environments and can be a source of vector transmission that is difficult to control. Ae. aegypti in two ecosystems treated on the media to lay eggs with the water's salinity levels showed a significant difference. Colony Ae. aegypti was able to lay many eggs in coastal areas, in contrast to inland colonies, which show fewer eggs at each salinity level. At the testing stage, mosquitoes can lay eggs at the highest salinity level (3 ppt), with a percentage of $27.1 \%$ for coastal colonies and $20.8 \%$ for inland colonies (Table 3 ).

\section{Correlation of survival and salinity of larvae Ae. aegypti}

Pearson correlation analysis showed significance at the larval instar stage of Ae. aegypti of both ecosystems with the ability to survive at the salinity level $(\mathrm{p}=0.000)$ (Table 4). 
Table 3. Characteristics ovitraps of Ae.aegypti oviposition in laboratory

\begin{tabular}{|c|c|c|c|c|c|c|c|c|c|c|}
\hline \multirow{2}{*}{ Salinity (ppt) } & \multicolumn{2}{|c|}{$1^{\text {st }}$ week } & \multicolumn{2}{|c|}{$2^{\text {nd }}$ week } & \multicolumn{2}{|c|}{$3^{\text {rd }}$ week } & \multicolumn{2}{|c|}{$4^{\text {th }}$ week } & \multicolumn{2}{|c|}{ Percent of total } \\
\hline & $\mathbf{R}$ & $\mathbf{M}$ & $\mathbf{R}$ & $\mathbf{M}$ & $\mathbf{R}$ & $\mathbf{M}$ & $\mathbf{R}$ & $\mathbf{M}$ & Coastal & Inland \\
\hline 0 & 211 & 210 & 161 & 170 & 115 & 84 & 78 & 53 & 40.3 & 59.0 \\
\hline 3 & 120 & 80 & 100 & 50 & 98 & 33 & 62 & 19 & 27.1 & 20.8 \\
\hline 5 & 90 & 36 & 50 & 40 & 41 & 21 & 26 & 13 & 14.8 & 12.5 \\
\hline 10 & 81 & 25 & 52 & 27 & 38 & 7 & 15 & 0 & 13.3 & 6.7 \\
\hline 15 & 29 & 0 & 15 & 0 & 9 & 0 & 4 & 0 & 4.1 & 0 \\
\hline 20 & 6 & 0 & 0 & 0 & 0 & 0 & 0 & 0 & 0.4 & 0 \\
\hline
\end{tabular}

Note: Ecosystem R: Randomayang colonies, M: Martajaya colonies

Table 4. Correlation of survival and salinity in each Ae. aegypti larvae instar in ecosystems

\begin{tabular}{llcc}
\hline \multirow{2}{*}{ Instar } & \multirow{2}{*}{ Correlation salinity } & \multicolumn{2}{c}{ Survive } \\
\cline { 3 - 4 } & & Coastal & Inland \\
\hline $1^{\text {st }}$ & Pearson Correlation & $-.888^{* *}$ & $-.937^{* *}$ \\
& Sig. (2-tailed) & 0.000 & 0.000 \\
$2^{\text {nd }}$ & Pearson Correlation & $-.901^{* *}$ & $-.922^{* *}$ \\
& Sig. (2-tailed) & 0.000 & 0.000 \\
\multirow{2}{*}{$3^{\text {rd }}$} & Pearson Correlation & $-.912^{* *}$ & $-.921^{* *}$ \\
& Sig. (2-tailed) & 0.000 & 0.000 \\
$4^{\text {th }}$ & Pearson Correlation & $-.918^{* *}$ & $-.861^{* *}$ \\
& Sig. (2-tailed) & 0.000 & 0.000 \\
\hline
\end{tabular}

Note: $* *$. Correlation is significant at the 0.01 level (2-tailed)
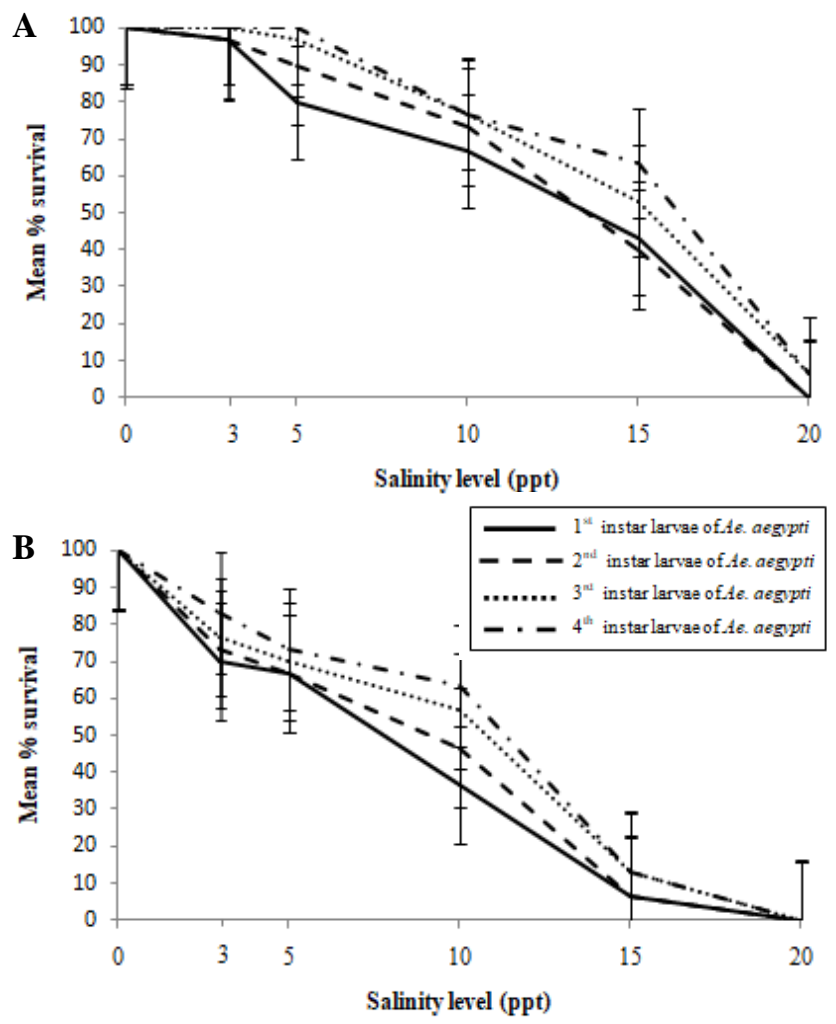

Figure 3. Survival larvae of Ae. aegypti in coastal (A) and inland (B)

\section{Discussion}

Dengue fever is an acute febrile illness caused by the dengue virus (DENV). Ae. aegypti is the primary vector of dengue fever, chikungunya, yellow fever, and the Zika virus worldwide. Mosquito Ae. aegypti can transovarially reduce the virus in mosquito heredity, especially in females (Le Coupanec et al. 2017; Soni et al. 2020; Souza et al. 2019). Indonesia is a tropical country that is very supportive of Ae. aegypti (Sasmono et al. 2015). The number of dengue hemorrhagic fever (DHF) in 2020 was 95.89 cases in Indonesia. The spread of dengue was fast, and mosquitoes were difficult to control (Ministry of Health, Republic of Indonesia 2020). Dengue fever in the West Sulawesi region in 2020 was 614 cases.

Distribution of larvae Ae. aegypti $(\mathrm{n}=2752)$ was found in two locations and the highest in coastal Randomayang $(n=1437)$. The highest percentage of larvae from the two habitats was in the type of container drum water, but the difference in the coastal is the water contains salinity in the container. Drum water was mostly found because people use it to collect water. Lack of clean water capacity is the reason residents use water drums as water reservoirs. Water drums were breeding places for Ae. aegypti in developing countries (Hemme et al. 2009; Ferede et al. 2018). Other studies reported the percentages of water drums being used as a breeding site for Ae. aegypti 19.3\% (Midega et al. 2006), 19.7\% (Ngugi et al. 2017), and 31.8\% (Tedjou et al. 2018).

Chemical characteristic of larval habitat is classified based on the salt content. Freshwater habitats have a salinity of $<0.5 \mathrm{ppt}$, brackish water 5 to $30 \mathrm{ppt}$, seawater 30 to $50 \mathrm{ppt}$, and brine water which is very rich in dissolved salts has a salinity > $50 \mathrm{ppt}$ (Lincoln et al. 1982). The coastal brackish and salty habitats consist of salt marshes, mangrove swamps, rock pools, and lakes. The littoral habitat zone has an ion ratio similar to that of seawater. The salinity of the brackish and salty habitats tends to fluctuate widely, decreasing due to rain or exposure to freshwater, and increases by evaporation. Sea level rise due to global warming could result from the expansion of naturally brackish surface water bodies in coastal areas and a further effect, namely the level of water withdrawal from freshwater aquifers in coastal areas by expanding the population of Nicholls et al. (2007). These conditions can lead to mosquito species emergence over a long period with different salinity suitability (Mosha and Mutero 1982).

Even though most mosquito larvae live in freshwater, there was $5 \%$ of species live in brackish or saltwater, such 
as the genera Aedes, Opifex, Prophora, Aedomyia, Culex, Uranotaenia, and Anopheles (O'Meara 1976). Various Aedes genera, such as Ae. togoi found in coastal marshes. Sea level rise can increase the abundance of mosquito vectors that can adapt to saline. An. giles was the first vector of malaria in Sri Lanka. Its freshwater habitat was adapted to undergo preimaginal development in brackish waters with 4 ppt salinity (Surendran and Ramasamy 2010). Besides, An. subpictus and An. sundaicus tolerated various salinities (euryhaline) in Sri Lanka. The larvae were isolated from freshwater with $30 \mathrm{ppt}$ water in the lagoon (Surendran et al. 2011).

Aedes. aegypti are generally only considered to reproduce only in freshwater, while mosquitoes can adapt to various environments (Rueda 2008). Ae. aegypti was found to adapt to coastal habitats close to human settlements (Ratnasari et al. 2020). The adaptation process of Ae. aegypti in saline habitat occurred in coastal areas because of the mixture of freshwater with seawater (Jude et al. 2010). The salinity tolerance of Ae. aegypti in coastal areas is an adaptive response to the extensive use of insecticides for agriculture in the inland area (Ramasamy and Surendran 2011).

In this study, larvae Ae. aegypti was not able to survive with a salinity of $20 \mathrm{ppt}$ from the coastal and inland in the laboratory. Decreased survival was rapid at 10 and $15 \mathrm{ppt}$ and $20 \%$ survival at $20 \mathrm{ppt}$ salinity. The adaptability of Ae. aegypti at $90 \%$ at $3.5 \mathrm{ppt}$ salinity, and $0 \%$ at $17.5 \mathrm{ppt}$ salinity (Clark et al. 2004). According to Ramasamy et al. (2014), larva Ae. aegypti from the coastal area survived with a salinity of $18 \mathrm{ppt}$ in the second generation of these mosquitoes. In the fifth generation, the mosquitoes adapted at a salinity of $20 \mathrm{ppt}$. The ability limit for Ae. aegypti tolerates a salinity of $17.5 \mathrm{ppt}$ (de Brito Arduino et al. 2015). The container sample contained saline content in most sampling locations except at a distance of more than 1 $\mathrm{km}$ from the coastline. On laboratory tests, the IV instar can tolerate salinity up to a salinity of $15 \mathrm{ppt}$.

Mosquito larvae in brackish waters can live for 24 hours at $1000 \mathrm{mOsm}$, but cannot mature unless salinity was lowered (Wigglesworth 1933; Bradley 1987). The osmoregulation mechanism of Ae. aegypti has an average hemolymph osmolarity in the freshwater of about 250 osmoles 1-1 (Hiscock et al. 2002). The larvae's capacity to regulate the osmotic pressure of salinity shows a difference in the hemolymph reaction (Edwards 1982b). Larva Ae. aegypti coastal areas tolerated a maximum salinity of 18 ppt $(500 \mathrm{mOsm})$, more than $18 \mathrm{ppt}$ larvae occurred osmoconformers (Garrett and Bradley 1984). Larva Ae. aegypti with low concentrations of artificial seawater, the media osmotic pressure approached hemolif. Hemolific osmotic pressure increases sharply when the concentration of salinity water increases (Edwards 1982a; Richards and Meier 1974). Salinity-tolerant arboviral disease vectors are a health problem in humans in the world (Rezza et al. 2007; Pfeffer and Dobler 2010). Adaptation of vectors in freshwater to brackish water can increase disease transmission by mosquitoes in coastal areas (Ramasamy and Surendran 2011). Anthropogenic-induced adaptive changes in vector mosquitoes can lead to range expansion, facilitating large areas' invasion (Ramasamy and Surendran 2016).

Oviposition study in the laboratory, adult Ae. aegypti in coastal adapted to a salinity of $15 \mathrm{ppt}$, unlike adult $A e$. aegypti from inland put eggs only at a salinity of $10 \mathrm{ppt}$. An eggs trapped in the ovitrap decreases if a higher salinity level. In general, adult Ae. aegypti in coastal Randomayang and inland Martajaya prefer to put eggs at a salinity of 3 ppt. According to the previous studies, colony oviposition of Ae. aegypti put eggs at a salinity of 1, 2.5, and $18 \mathrm{ppt}$ (Rammasamy et al. 2011; Panigrahi et al. 2014; Yap et al. 1995).

In this study, the results of Person analysis with a significance value of 0.01 showed that the survival rate of instar larva I, II, III, and IV in both habitat ecosystems significantly showed a relationship to the adaptation of each salinity level with $\mathrm{p}<0.001$. According to Rammasamy et al. (2011), the survival of larvae in inland and coastal ecosystems has a significant value for salinity with a p-value of 0.01 . In the research of Mukhopadhyay et al. (2010), the survival rate of larvae with $\mathrm{NaCl}$ with a salinity concentration of $1.50 \%$ is directly related to larval mortality of $50 \%-90 \%$ at $19-29$ hours. Salinity can affect the size of the anal papillae in larvae Ae. aegypti (Surendran et al. 2018). According to Kengne et al. (2019), the adaptability of Ae. aegypti larvae to salinity show a correlation in larval hemolymph in maintaining osmolarity with salinity tolerance with P-value $<0.05$.

This study concluded that no current evidence for the large-scale adaptation of Ae. aegypti undergoing preimaginal development in natural brine. But on a laboratory scale, Ae. aegypti can survive, tolerate salinity, and put eggs of up to $15 \mathrm{ppt}$. Until recently, the application of vector control methods still prioritizes freshwater habitats in urban environments. Brackish water on abandoned in coastal Randomayang could change the adaptation pattern of Ae. aegypti in the future. This change is a serious concern regarding health since the high dengue hemorrhagic fever is associated with Ae. aegypti adapted in inland and coastal of Pasangkayu District. Data on the availability of Ae. aegypti habitats in this overlooked area should be warning the vector control program that coastal areas need to be a concern, especially dengue fever because this outbreak can occur at any time.

\section{ACKNOWLEDGEMENTS}

The authors wish to thank PMDSU Scholarship from the Indonesian Ministry of Education and Culture and the Faculty of Medicine, Hasanuddin University, Makassar, Indonesia, for supporting this research.

\section{REFERENCES}

Augustina I, Jabal AR, Permana GI, Ratnasari AR. 2020. Distribution and ecology of mosquito larvae in Pahandut Sub-District Palangka Raya City. J Phys: Conf Ser ICMSE 2020 [in the publish stage]. [Indonesian] 
Bradley TJ. 1987. Physiology of osmoregulation in mosquitoes. Ann Rev Entomol 32: 439-462.

Clark TM, Flis BJ, Remold SK. 2004. Difference in the effects of salinity on larval growth and developmental programs of a freshwater and a euryhaline mosquito species (Insecta: Diptera, Culicidae). J Exp Biol 207: 2289-2295

de Brito Arduino M, Mucci LF, Serpa LL, de Moura Rodrigues M. 2015 Effect of salinity on the behavior of Aedes aegypti populations from the coast and plateau of southeastern Brazil. J Vector Borne Dis 52 (1): $79-87$.

Edwards HA. 1982a. Aedes aegypti: Energetic of osmoregulation. J Exp Biol 101: 135-141.

Edwards HA. 1982b. Ion concentration and activity in the hemolymph of Aedes aegypti larvae. J Exp Biol 101: 143-151.

Ferede G, Tiruneh M, Abate E, Kassa WJ, Wondimeneh Y, Damtie D, Tessema B. 2018. Distribution and larval breeding habitats of Aedes mosquito species in residential areas of northwest Ethiopia. Epidemiol Health 40. DOI: 10.4178/epih.e2018015.

Garrett M, Bradley TJ. 1984. The pattern of osmotic regulation in larvae of the mosquito Aedes aegypti. J Exp Biol 133: 133-141.

Hemme RR, Tank JL, Chadee DD, Severson DW. 2009. Environmental conditions in water storage drums and influences on Aedes aegypti in Trinidad, West Indies. Acta Trop 112 (1): 59-66. DOI 10.1016/j.actatropica.2009.06.008

Hiscock KM, Rivett MO, Davidson RM. 2002. Sustainable groundwater development. Geol Soc Lond Spec Publ 193 (1): 1-14. DOI: 10.1144/GSL.SP.2002.193.01.01

Idris FH, Usman A, Surendran SN, Ramasamy R. 2013. Detection of Aedes albopictus pre-imaginal stages in brackish water habitats in Brunei Darussalam. J Vect Ecol 38: 197-199.

Jude PJ, Dharshini S, Vinobaba M, Surendran SN, Ramasamy R. 2010 Anopheles culicifacies breeding in brackish waters in Sri Lanka and implications for malaria control. J Malar 9: 106.

Kengne P, Charmantier G, Blondeau-Bidet E, Costantini C, Ayala D. 2019. Tolerance of disease-vector mosquitoes to brackish water and their osmoregulatory ability. Ecosphere 10 (10): e02783. DOI: $10.1002 / \mathrm{ecs} 2.2783$

Le Coupanec A, Tchankouo-Nguetcheu S, Roux P, Khun H, Huerre M, Morales-Vargas R, Enguehard M, Lavillette D, Missé D, Choumet V. 2017. Co-infection of mosquitoes with chikungunya and dengue viruses reveals modulation of the replication of both viruses in midguts and salivary glands of Aedes aegypti mosquitoes. Int $\mathbf{J} \mathrm{Mol}$ Sci 18: 1708 .

Lincoln RJ, Boxshall GA, Clark PF. 1982. A Dictionary of Ecology, Evolution and Systematics. Cambridge University Press, Cambridge.

Midega JT, Nzovu J, Kahindi S, Sang RC, Mbogo C. 2006. Application of the pupal/demographic-survey methodology to identify the key container habitats of Aedes aegypti (L.) in Malindi District, Kenya. Ann Trop Med Parasitol 100: 61-72. DOI: 10.1179/136485906X105525.

Ministry of Health, Indonesia. 2017. Guidelines for Dengue Fever Entomology Survey and Key to Identification of Aedes Mosquitoes. Ministry of Health, Jakarta. [Indonesian]

Ministry of Health, Indonesia. 2020. Dengue fever case report in Indonesia. [Indonesian]

Mosha FW, Mutero CM. 1982. The influence of salinity on larval development and population dynamics of Anopheles merus Donitz (Diptera: Culicidae). Bull Entomol Res 72: 119-128.

Mukhopadhyay AK, Tamizharasu W, Satya BP, Chandra G, Hati AK. 2010. Effect of common salt on laboratory-reared immature stages of Aedes aegypti $(\mathrm{L})$. Asian Pac J Trop Med 3 (3): 173-175.

Ngugi HN, Mutuku FM, Ndenga BA, Musunzaji SP, Mbakaya JO, Aswani P, Irungu LW, Mukoko D, Vulule J, Kitron U, LaBeaud AD 2017. Characterization and productivity profiles of Aedes aegypti (L.) breeding habitats across rural and urban landscapes in western and coastal Kenya. Parasites Vectors 10 (1): 1-12. DOI: 10.1186/s13071017-2271-9.

Nicholls RJ, Wong PP, Burkett V, Codignotto J, Hay J, McLean R, Ragoonaden S, Woodroffe CD, Abuodha PA, Arblaster J, Brown B 2007. Coastal systems and low-lying areas. In: Parry ML, Canziani OF, Palutikof JP, van der Linden PJ, Hanson CE (eds) Climate Change 2007: Impacts, Adaptation, and Vulnerability, Contribution of Working Group II to the Fourth Assessment Report of the Intergovernmental Panel on Climate Change. Cambridge University Press, Cambridge.
O'Meara GF, Evans DG. 1976. The influence of mating on autogenous egg development in the mosquito Aedes taeniorhynchus. J Insect Physiol 22: 613-617.

Panigrahi SK, Barik TK, Mohanty S, Tripathy NK. 2014. Laboratory evaluation of oviposition behavior of field collected Aedes mosquitoes 2014. J Insect. DOI: 10.1155/2014/207489.

Pfeffer M, Dobler G. 2010. Emergence of zoonotic arboviruses by animal trade and migration. Parasit Vectors 3: 35

Ramasamy R, Surendran SN. 2011. Possible impact of rising sea levels on vector-borne infectious diseases. BMC Infect Dis 11: 18

Ramasamy R, Surendran SN, Jude PJ, Dharshini S, Vinobaba M. 2011. Larval development of Aedes aegypti and Aedes albopictus in periurban brackish water and its implications for transmission of arboviral diseases. PLoS NTDs 5 (11): e1369. DOI: 10.1371/journal.pntd.0001369

Ramasamy R, Surendran SN. 2012. Global climate change and its potential impact on disease transmission by salinity-tolerant mosquito vectors in coastal zones. Front Physiol 3: 198. DOI: 10.3389/fphys.2012.00198.

Ramasamy R, Jude PJ, Veluppillai T, Eswaramohan T, Surendran SN. 2014. Biological Differences between Brackish and Fresh WaterDerived Aedes aegypti from Two Locations in the Jaffna Peninsula of Sri Lanka and the Implications for Arboviral Disease Transmission. PLOS ONE 9: 8. DOI: https://doi.org/10.1371/journal.pone.0104977.

Ramasamy R, Surendran SN. 2016. Mosquito vectors developing in atypical anthropogenic habitats-global overview of recent observations mechanisms and impact on disease transmission. J Vector Borne Dis 53: 91-8.

Ratnasari A, Jabal AR, Rahma N, Rahmi SN, Karmila M, Wahid I. 2020. The ecology of Aedes aegypti and Aedes albopictus larvae habitat in coastal areas of South Sulawesi, Indonesia. Biodiversitas 21: 46484654. DOI: https://doi.org/10.13057/biodiv/d211025.

Rezza G, Nicoletti L, Angelini R, Romi R, Finarelli AC, Panning M, Cordioli P, Fortuna C, Boros S, Magurano F, Silvi G. 2007. Infection with chikungunya virus in Italy: an outbreak in a temperate region. Lancet 370: 1840-1846.

Richards AG, Meier TJ. 1974. The osmolarity of the blood of a mosquito larvae (Aedes aegypti L.) reared under several different culture conditions. Ann Entomol Soc Am 67: 424-6.

Rueda LM. 2008. Freshwater Animal Diversity Assessment. DOI: 10.1007/978-1-4020-8259-7.

Sasmono RT, Wahid I, Trimarsanto H, Yohan B, Wahyuni S, Hertanto M, Yusuf I, Mubin H, Ganda IJ, Latief R, Bifani PJ, Shi PY, Schreiber MJ. 2015. Genomic analysis and growth characteristic of dengue viruses from Makassar, Indonesia. Infect Genet Evol 32: 165-177. DOI: 10.1016/j.meegid.2015.03.006.

Soni M, Khan SA, Bhattacharjee CK, Dutta P. 2020. Experimental study of dengue virus infection in Aedes aegypti and Aedes albopictus: A comparative analysis on susceptibility, virus transmission and reproductive success. J Invertebr Pathol 175: 107445.

Surendran SN, Kajatheepan A, Sanjeefkumar KF, Jude PJ. 2007. Seasonality and insecticide susceptibility of dengue vectors: An ovitraps based survey in a residential area of northern Sri Lanka. Southeast Asian J Trop Med Public Health 38: 276-282.

Surendran SN, Ramasamy R. 2010. The Anopheles culicifacies and Anopheles subpictus species complexes in Sri Lanka and their implications for malaria control in the country. Trop Med Health 38: $1-11$.

Surendran SN, Jude PJ, Ramasamy R. 2011. Variations in salinity tolerance of malaria vectors of the Anopheles subpictus complex in Sri Lanka and the implications for malaria transmission. Parasite Vectors 4: 117

Surendran SN, Jude PJ, Thabothiny V, Raveendran S, Ramasamy R. 2012. Pre-imaginal development of Aedes aegypti in brackish and freshwater urban domestic wells in Sri Lanka. J Vect Ecol 37 (2): 471-473.

Surendran SN, Sivabalakrishnan K, Jayadas TT, Santhirasegaram S, Laheetharan A, Senthilnanthanan M, Ramasamy R. 2018. Adaptation of Aedes aegypti to salinity: Characterized by larger anal papillae in larvae. J Vector Borne Dis 55: 235-238.

Souza NJA, Powell JR, Bonizzoni M. 2019. Aedes aegypti vector competence studies: A review. Infect Genet Evol 67: 191-209. DOI: 10.1016/j.meegid.2018.11.009.

Tedjou AN, Kamgang B, Yougang AP, Njiokou F, Wondji CS. 2018. Update on the geographical distribution and prevalence of Aedes aegypti and Aedes albopictus (Diptera: Culicidae), two major 
arbovirus vectors in Cameroon. PLoS NTDs 13 (3): 1-18. DOI: 10.1371/journal.pntd.0007137.

Wheeler MW, Park RM, Bailer J. 2009. Comparing median lethal concentration values using confidence interval overlap or ratio tests. Environ Toxicol Chem 25: 1441-1444.
Wigglesworth VB. 1933. The adaptation of mosquito larvae to saltwater. J Exp Biol 10: 27-37.

Yap HH, Lee CY, Chong NL, Foo AE, Lim MP. 1995. Oviposition site preference of Aedes albopictus in the laboratory. J Am Mosq Control Assoc 11: 128-132. 